\begin{tabular}{|c|ccc|}
\hline \multicolumn{3}{|c|}{ ADIYAMAN ÜNIVERSITESI SOSYAL BILIMLER ENSTITÜSÜ DERGISI } \\
ISSN: 1308-9196
\end{tabular}

\title{
TÜRKÇE DERSINDE DRAMAYLA ÖYKÜ OLUŞTURMA YÖNTEMININ ÖĞRETMEN GÖRÜŞLERINE GÖRE DEĞERLENDIRILMESi ${ }^{1}$
}

\section{Ömer Tuğrul KARA*}

$\ddot{O}_{z e t}$

Bu çalışmada ilköğretim ikinci kademe Türkçe dersinin nasıl daha iyi öğretileceği konusunda dramayla öykü oluşturmaya dayalı bir eğitim yöntemi önerilmiştir. Türkçe dersinde bu yöntemin temel dil becerilerinin, yaratıcılık ve hayal gücünün geliştirilmesinde, dil bilgisi öğretiminde etkili olacağı düşünülmektedir.

Araştırmanın örneklemini Osmaniye ilinde görev yapan 44 Türkçe öğretmeni oluşturmaktadır. Yöntem üzerine öğretmen görüşlerini belirlemeye yönelik anket uygulamasında ise tarama modeli kullanılmıştır. Araştırmada "Dramayla Öykü Oluşturma Yöntemi Öğretmen Anketi" uygulanmıştır. Anketlerin verileri incelendiğinde dramayla oluşturulmuş öykülerle işlenen Türkçe dersinin daha kalıcı olduğu, bu yöntemin Türkçe derslerinde kolaylıkla uygulanabileceği ve dramayla öykü oluşturma yönteminin ilköğretim programında yer almasının faydalı olacağı sonucu ortaya çıkmıştır.

Anahtar Kelimeler: Türkçe Eğitimi, Drama, Öykü Oluşturma

\section{THE EVALUATION OF METHOD OF STORY FORMATION WITH DRAMA ACCORDING TO TEACHERS' OPINIONS IN TURKISH LESSONS}

\begin{abstract}
Abstarct
In this study, it has been recommended an education method based on story formation with drama on the subject of how Turkish lesson in primary school at the second degree could be taught better. This method is thought to be effective in Turkish lessons on the improvement of imaginative power, creativity and major language skills and on teaching grammar.

44 Turkish teachers, teaching in Osmaniye, constitute the samples of the study. Scanning model was used for the application of the survey in order to determine teachers' opinions on the method. In the study, survey of the method of story formation with drama for teachers was applied. When data of the surveys were studied, it has been concluded that Turkish lesson that has been taught with the stories made up with drama is more permanent and this method could easily be used in Turkish lessons and taking place of the method of story formation with drama in the curriculum of primary schools would be beneficial.
\end{abstract}

Key Words: Turkish Education, Drama, Story Formation

\section{GiRiş}

Günümüzde öğrenme faaliyetleri içinde bilgiyi etkili ve kalıcı kılacak çeşitli yöntem ve teknikler kullanma gereği ön plana çıkmıştır. Çağdaş eğitim yöntemleri yaratan, yorumlayan, kendini ifade edebilen, öğrendiklerini yaşama aktarabilen bireyler yetiştirir. Çağdaş eğitimin işaret ettiği yeni yöntemleri de özümsemek, özümserken

\footnotetext{
${ }^{1}$ Bu çalışma, Selçuk Üniversitesi Eğitim Bilimleri Enstitüsü, Türkçe Eğitimi Ana Bilim Dalında 2010 yılında tamamlanan "Dramayla Öykü Oluşturma Yönteminin İlköğretim İkinci Kademe Türkçe Öğretimine Etkisi” adlı doktora tezinin verilerinden yararlanılarak hazırlanmıştır.

Yrd. Doç. Dr., Çukurova Üniversitesi, Eğitim Fakültesi, Türkçe Eğitimi Bölümü, gevheri76@hotmail.com
} 
uygulayabilmek gerekir. Yeni Türkçe Programı öğrencilerin eğitim sürecine katılmasını sağlayacak etkinlikleri temel alır. Bu çerçevede yeni program yaparak, yaşayarak öğrenme merkezli yöntem ve tekniklere yer vermiştir. Eğitimcilerin ortama ve verilecek bilgiye uygun yöntemler kullanarak bilindik kuralların dışına çıkmaları, kendi anlayışlarını sınıf ortamına getirmeleri gerekir. Bilgi beceriye dönüştürülerek, gerçek yaşamla ilişkilendirilmelidir. Bilgiyi yaşama taşımak ve gelecek kuşaklara aktarmak, onların yeniliğe açık, üretken ve yaratıcı olmalarını sağlayacak öğretim modellerini geliştirmek hayati bir zorunluluktur. Eğitim öğretimde çok farklı yöntemler kullanılır.

"Eğitim programının kişiyi istenilen sonuca ulaştırmaması eğitimde bazı yeni yaklaşımların kullanılmasını da gerekli kılmıştır. Yeni programlar hazırlanırken de dünyadaki yenilikler takip edilerek bu yenikliklere ayak uydurabilen insanlar yetiştirmek amaç edinilmiştir. Programlar, etkinliklerle zenginleştirilerek, öğrenci merkezli hâle getirilmiştir. Yaratıcı düşünce ve eylemler daha fazla desteklenmiş ve başarıyı notla ölçen, sonuca dayalı bir anlayış yerine, öğrencinin ders içi başarısını da değerlendiren bir anlayış esas alınmıştır" (İşleyen, 2009: 2)

$\mathrm{Bu}$ yeni yöntemlerden biri de öğrencilerin derse zevkle katılmalarını sağlayan, dersi günlük yaşamla ilişkilendiren dramadır. Drama kavramının çok değişik tanımlarına rastlanmakla birlikte tam olarak Türkçe karşılığı yoktur. "Drama sözcüğünün kökü Yunanca 'Dran'dır. Dran; itmek, çekmek, yapmak, etmek, eylemek anlamlarında kullanılır. Bütün bu verilere dayanarak drama sözcügünün, içinde eylem olan her türlü etkinliği içerdiği söylenebilir" (Adıgüzel, 2007: 15). Çağdaş anlamda “dram” ve “drama” kavramları üzerine farklı tanımlar yapılmıştır: Drama, sahnede oynanmak için oluşturulmuş, konuşmalar ve hareketlerle gelişen, oyundur. "En yalın anlamıla drama; dramatik bir durumun, bir grup tarafından tiyatro teknikleri kullanılarak paylaşılması sürecidir" (Aslan, 2009: 27). "Daha ayrıntılı bir tanımla, insanın insanla giriştiği her tür dolaysız, doğrudan ilişki, etki tepki alışverişi, arada oluşan en az düzeyde bir etkileşim bile bir dramatik an ya da dramatik bir durumdur" (San, 1990: 573).

Tanımlardan da anlaşılacağı gibi drama insanın duygularını ve düşüncelerini harekete dönüştürebileceği en iyi yollardan biridir ve tamamen yaşamla ilgilidir. İnsan yaşamı belli davranışlardan ve dramatik unsurlardan oluşan zincirleme hareketlerden ibarettir. Yaşamdaki yerimizi drama vasıtasıyla daha iyi algılayabiliriz. Dramayla öğrenciler kendi yaşamlarındaki küçük öyküleri canlandırma fırsatını yakalamaktadırlar. Bu öykülerin canlandırılması alanın araştırmacıları tarafından "öykü draması" (Özcan, 2004: 40) ve "dramaya dayalı hikâye" (Uyar, 1995: 20); (İpek, 1998: 26) gibi isimlerle ifade edilmektedir. Dramayla öykü oluşturma, öykülerin öğrencilere olan etkisinden yola çıkarak bilinen ya da doğaçlama yoluyla oluşturulan öykülerin drama teknikleri kullanılarak canlandırılmasıdır. Öyküleştirme, insanları anlamanın bir yolu olduğu kadar, kim olduğumuzu, ne yaptığımızı, neler hissettiğimizi ve neden belirli bir davranış biçimini izlediğimizi açıklamanın da bir biçimidir. Bir öyküde bir takım insanların başlarından geçen olaylar, onlara ait fikirler, teoriler ve hayaller onların bakış açıları doğrultusunda yer almaktadır. Bireyler, öyküdeki ögeler ve öykünün yapısı uyarınca düşünmekte, algılamakta, yorumlamakta, hayal etmekte, etkileşime girmekte ve sonuçlara varmaktadır (Yiğit, 2007: 13-14). 
Öyküleri eğitimde yöntem olarak kullanmaya elverişli kılan anahtar roldeki kavramlar "taklit, özdeşim kurma ve empati”dir. Çocuk hayat boyunca öğrendiği pek çok şeyi farkında olarak veya olmayarak çevresini taklit yoluyla öğrenir. İlköğretim basamağındaki çocuk için öykü, öyküde geçen kahramanlar ve onların duygularıyla özdeşleşmek çok zor olmasa gerektir. Nitekim bilişsel psikoloji alanında yapılan çalışmalar, öykü formundaki metinleri okuyan çocukların, öyküde sunulan düşüncelerin \% 88'ini anımsayabildiklerini göstermektedir. Kullanılış amaç ve içeriği, sınıfta uygulama boyutları farklı olmakla birlikte, bir öğretim yöntemi olarak öykü, bilimsel perspektif ve düşünüşün öğrenciye kazandırılması ve kavramsal anlamanın gerçekleştirilmesi için eğitimde kullanılmaktadır (Çakar, 2007: 20). Dramayla öykü kullanımının eğitim açısından pek çok kazanımı vardır: Çocuk, öykü ve dolayısıyla içindeki yaşantı ürünü ya da kurgusal gerçeklikle gerçek hayatta karşıı̆ını ya da çözümünü bulamadığı birçok meseleyi anlamlandırabilir ve çözebilir (Uzuner, 2007: 11). Öykü oluşturma etkinlikleri sırasında öğrencinin aktif olarak rol aldığı bir süreç gerçekleşmiş olacaktır. Öyküyü canlandırmayla öğrenci gerçek yaşama ilişkin problemleri inceleme, analiz etme ve çözme imkânına sahip olacaktır. "Öykü kurma alıștırması ile çocukların sözel becerilerindeki yaratııılık ve hayal gücünün harekete geçirildiği gözlenmektedir" (Bayer, 2006: 61). Dramayla öykü oluşturma çalışmalarında metinler, olaylar ve duygular canlandırııır ve öğrenciler farklı karakterleri oynarlar. Özellikle karşılıklı konuşma metinleri böyle bir uygulama için elverişli olur. Bu canlandırmalar esnasında öğrenci bazen bir insan bazen bir hayvan hatta cansız bir varlık olabilir. Bu bir empati kurma durumudur. Öğrenci, öyküyü dinlediği durumdan farklı olarak öyküyü yaşar.

Dramayla öykü oluşturma kahraman, hedef, engel / olay, eylem gibi temel unsurlardan meydana gelmiştir. Öyküleştirme etkinlikleri içinde kahramansız olay ya da durum söz konusu olamaz. Kahramanın ya da kahramanların tek amacı içinde bulundukları çatışmadan ve gerilimden kurtulmaktır. Her öykü bir olayı ve durumu içinde barındıır. Öyküde yaşanan olaylar ve durumlar gerçekte insanın hayallerini umutlarını, dileklerini temsil eder. Dramatik bir yapının içerisinde sahnede oynanmaya uygun çatışma, gerilim, zıtlıklar, coşku ve heyecan veren durumlar vardır. Bu yapı etkileyici, sürprizlerle dolu ve birdenbire olan olayları gözler önüne serer. Dramatik yapıyla şekillendirilmiş bir öykü izleyicileri kendine çekecek, öğrencilerin öykü içindeki rollerinde oynama isteğini arttıracaktır. Dramatik yapıyı belirleyen en önemli unsurlardan biri de "çatışma"dır. Çatışma, aynı anda çıkan birbirine karşıt ya da eşit derecede çekici dilek, istek ya da ereklerin yarışmasından ortaya çıkan üzücü ya da kıvanç vermekten uzak bilinç durumudur (Oğuzkan, 1993: 26). Çatışma, öykü içerisinde sorun ya da sorunları ortaya çıkarır ve dramatik yapıyı geliştirir. Dramayla öykü oluşturma etkinliğinin oynanabilir olma özelliği çatışma üzerine kuruludur. "Dramatik unsurlardan biri olan çatışma öyküde olay içinde yer almaktadır. Bu çatışma yazarı özel bir yapılandırmaya götürür. Çünkü her olayın bir çıkış, bir gelişsim bir de sona eriş aşaması vardır. Öyküde çatışma giriş, gelişme ve sonuç bölümleri ile ve bu bölümlerin birbiri ile bağlantısı yapılandırılarak sonuçlandırıır" (Aksoy Tokgöz, 2004: 19). Gerilim ise belirsizlik ve rastlantıya dayanmaktan çıkar; bu belli bir sonuca ulaşmak, onu elde etmek için bir çabalama, bir uğraşmadır, başarı için bu çabada bir gerilim vardır (And, 1974: 15). Kahramanlar çatışmayı çözmek için uğraş verirken belli bir düzeyde gerilim yaşarlar. Dramayla öykü oluşturma etkinlikleri çeşitli engeller içerir. Çatışmalar ve sorunlardan oluşan bu engeller oynayanda, izleyende belirli bir gerilim noktası meydana getirir. Bu unsurlarla yoğunlaşmı̧ öykülerin canlandııımasında öğrenciler kendilerini öykülerdeki kahramanların yerine koyarak ideal çözüm yolları bulma 
yoluna giderler. "Eylem" dramanın doğasında olan bir unsurdur. Dramayla öykü oluşturma etkinliklerinde eylemin seyirlik olması gerekir. İyi bir dramatik yapı, kişiyi eyleme sürükler. Oyun kişilerinin çatışmalarını ve isteklerini somutlaştırdıkları unsur eylemdir. Dramayla öykü oluşturma yöntemi "kahraman, öykü / olay ve eylem" gibi temel unsurların yanı sıra "konuşma örgüsü ve metaxis (dramatik var olma)" gibi yardımcı unsurları da içerir.

Dramayla öykü oluşturma etkinliklerinde hedeflenen kazanımlara uygun olarak doğrudan bir metin ya da olaydan öykü oluşturma, yarım bırakılmış öyküyü tamamlama, mevcut öykünün ögelerini değiştirme, çağrışım ve doğaçlama yoluyla öykü oluşturma gibi modellere yer verilir.

Araştırma özellikle dramanın bir yöntem ve öğretim modeli olarak önemini vurgulamak, ilköğretim ikinci kademe Türkçe derslerinde dramayla öykü oluşturma yönteminin uygulanabilirliğini öğretmenler aracılığıyla göstermek amacıyla hazırlanmıştır. Drama, daha çok okul öncesi eğitiminde ve ilköğretimin birinci kademesinde kullanılan bir yöntem olarak bilinmektedir. Bu çerçevede Karakuş (2000) ve Aksoy Tokgöz (2004) öykünün öğretiminde ve yazımında dramanın kullanılmasını incelemişler, ancak bu çalışmalar ilköğretim birinci kademeyle ve öykünün bir edebî tür olarak ele alınmasıyla sınırlı kalmıştır. İlköğretim ikinci kademe derslerinde drama yönteminin kullanılması son dönemlerde başlamış, özellikle ikinci kademe Türkçe derslerinde bu yöntemin kullanabilirliliği sınırlı sayıdaki araştırmalarla gösterilmeye çalışılmıştır (Kara, 2000; Akar, 2000; Köklü, 2003; Karateke, 2006; Sönmez, 2006; Ünsal, 2005; Kazıcı, 2008; Koç, 2009). Ancak genelde bu çalışmalar da dramanın temel dil becerileri üzerine etkisi, atasözlerin ve deyimlerin öğretilmesinde dramanın kullanılması, drama ve yaratıcı dramanan karşılaştırılması, iletişim ve drama ilişkisi gibi konularla sınırlı kalmıştır. Bunlar içerisinde Türkçe öğretiminde drama yönteminin öğretmen gözüyle değerlendirildiği bir çalışma yoktur. Bu çalışmada Türkçe dersinin birçok alanına hitap eden dramayla öykü oluştuma yöntemi tanıtılmış, yöntemle ilgili etkinlik örnekleri hazırlanarak öğretmenlerin görüşlerine sunulmuştur.

\section{PROBLEM DURUMU}

Dramayla öykü oluşturma yöntemi bir konuyu öğretirken empati kurdurması, iletişim ve etkileşim becerilerini kazandırması, temel dil becerilerini geliştirmesi, yaratıcılığı arttırması, derse olan ilgi ve merakı yüksek seviyede tutması ile Türkçe eğitimini olumlu yönde desteklemektedir. Drama eğitim ve öğretimi bir arada tutabilen bir yöntemdir. Bu yönüyle Türkçe derslerinde kullanılmaya en uygun yöntemlerden biridir. Bu anlamda araştırmanın problem cümlesi “ilköğretim ikinci kademe Türkçe dersinde dramayla öykü oluşturma yöntemiyle ilgili öğretmen görüşleri nelerdir?" şeklinde ifade edilebilir.

\section{Araştırmanın Amacı ve Önemi}

Dramayla öykü oluşturma yönteminin Türkçe dersinde temel becerilerin kazandırılmasında etkili olacağı hedeflenmektedir. Bu genel amaç çerçevesinde ilköğretim ikinci kademe öğrencileriyle uygulama yapılmış öğretmenlerin yöntem hakkındaki görüşleri anket çalışmasıyla ortaya koyulmaya çalışılmıştır. Türkçe dersi bir beceri dersidir. Türkçe dersinde de diğer derslerde olduğu gibi ezbercilikten kaçınmak gerekir. Bunu 
gerçekleştirmek için etkin ve yaratıcı öğretim yöntemlerine yer verilmelidir. Araştırmada, ikinci kademe Türkçe dersinin kazanımları göz önünde tutularak dramayla öykü oluşturmaya dayalı bir öğretim yöntemi geliştirilmiştir. Sözü edilen yöntemin içeriğinde kazanımlara yönelik uygulama örnekleri verilmiş ve öğrencilerle uygulama çalışmaları yapılmış tüm bu program Türkçe öğretmenlerinin görüşlerine sunularak yöntem hakkında bir değerlendirme ortaya konmuştur. Dramayla öykü oluşturma yönteminin Türkçe derslerinde uygulanmasının özellikle ilköğretim ikinci kademede yeni yöntem ve tekniklerin kullanılmasına ilişkin eksikliğin giderilmesinde etkili olabileceği düşünülmektedir.

\section{Araştırmanın Sınırlılıkları}

1. Araştırma drama etkinliklerinin öykü oluşturma boyutuyla sınırlıdır.

2. Araştırma ilköğretim ikinci kademe Türkçe dersleriyle sınırıdır.

3. Araştırma 44 Türkçe öğretmeniyle sınırlıdır.

4. Araştırma Osmaniye iliyle sınırlıdır.

\section{YÖNTEM}

İlköğretim ikinci kademe Türkçe dersinde dramayla öykü oluşturma yöntemi üzerine öğretmen görüşlerini belirlemeye yönelik anket uygulaması tarama modelindedir. Tarama modeli geçmişte ya da hâlen var olan bir durumu var olduğu şekliyle betimlemeyi amaçlayan araştırma yaklaşımlarıdır. Araştırmaya konu olan olay, birey ya da nesne, kendi koşulları içinde ve var olduğu gibi tanımlanmaya çalışılır. Onları herhangi bir şekilde değiştirme, etkileme çabası gösterilmez. Önemli olan, onu uygun bir biçimde belirleyebilmektir (Karasar, 1991: 77).

\section{Araştırmanın Evreni ve Örneklemi}

Araştırmanın evreni Osmaniye ilindeki ilköğretim okullarıdır. Araştırmanın örneklemini 2009-2010 öğretim yılında Osmaniye ilinde görev yapan 44 Türkçe öğretmeni oluşturmaktadır.

\section{Veri Toplama Aracı}

Bu çalışmada veriler “Dramayla Öykü Oluşturma Yöntemi Öğretmen Anketi”yle toplanmıştır. Araştırmada ikinci kademe Türkçe dersinde drama yöntemiyle oluşturulmuş öykülerle ilgili öğretmen görüşlerini ortaya koymak amacıyla araştırmacı tarafından geliştirilen anket formu kullanılmıştır. Anket formu hazırlanırken, ilgili literatür taranmış, benzer araştırmalarda kullanılan anket formları incelenmiştir. Yapılan araştırmalardan ve Türkçe eğitimi programının kazanımlarından yola çıkarak, bu araştırmanın konusu ile ilgili taslak anket formu hazırlanmıştır. Geliştirilen bu taslak anket formunun, kapsam ve dil geçerliğini sağlamak için, 12 Türkçe öğretmenine uygulanarak bir ön çalışma yapılmıştır. Bu pilot çalışma sonucunda elde edilen verilerden hareketle anket formu yeniden düzenlenmiştir. Geliştirilen anket sorularının, geçerliliğini sağlamak için uzman görüşüne başvurulmuştur. Bu doğrultuda anket, Türkçe eğitimi ve eğitim bilimleri alanında uzman öğretim elemanlarına sunulmuş, gelen eleştiriler doğrultusunda anket soruları gözden geçirilmiş ve son şeklini almıştır. 
Araştırmada kullanılan anket formu, iki bölümden oluşmaktadır. Birinci bölümde kişisel-mesleki ve dramayla ilgili genel bilgileri içeren sorulara, ikinci bölümde ise dramayla öykü oluşturma yöntemine ilişkin öğretmen görüşlerine yer verilmiştir. Birinci bölümde araştırmaya katılan öğretmenlere ilişkin kişisel bilgiler ile ilgili ifadeleri içeren 7 soru, drama bilgileriyle ilgili ifadeleri içeren 9 soru bulunmaktadır. İkinci bölümde ise dramayla öykü oluşturma yönteminde karşılaşılan olumlu / olumsuz durumlarla ilgili ifadeleri içeren 15 soru bulunmaktadır. İkinci bölümdeki anket 5'li Likert tipi sorulardan oluşmaktadır. Bu anketin güvenirliğinin hesaplanmasında Cronbach Alpha katsayısı 0,73 olarak bulunmuştur. Bu da ölçme aracının iç tutarlığının yüksek olduğunu göstermektedir.

\section{Verilerin Toplanması ve Çözümlenmesi}

Öğretmen anketinin ve dramayla öykü oluşturma etkinliklerinin uygulanması için Osmaniye il Millî Eğitim Müdürlüğünden ve ilköğretim okullarından gerekli izinler alınmıştır. Araştırma kapsamında okulun Türkçe öğretmenleriyle sınıfların genel özellikleri ve öğrenciler hakkında görüş alış-verişinde bulunulmuştur. Bu çerçevede araştırmacı tarafından bir uygulama planı hazırlanmıştır. Araştırmanın uygulama planı aşağıda verilen çalışma planına göre yürütülmüştür:

1) Uygulamaya geçilmeden önce araştırmacı tarafından “dramayla öykü oluşturma” yönteminin teorik kısmı oluşturulmuştur. Teorik kısımda; "drama ve öykü ilişkisi, dramayla öykü oluşturmanın unsurları, model örnekleri, yöntemin planlanması ve temel dil becerilerine, yaratıcılığın geliştirilmesine, dil bilgisi öğretimine katkısı" üzerinde durulmuştur. Daha sonra araştırmacının hazırladığı öğretmen anketi ve etkinlik örnekleri uzman görüşleri çerçevesinde son şeklini almıştır.

2) 22.04.2010-28.05.2010 tarihleri arasında "Dramayla Öykü Oluşturma Yöntemi Öğretmen Anketi” Osmaniye ilindeki millî eğitime bağlı resmî okullardaki 44 Türkçe öğretmeniyle birebir görüşülerek uygulanmıştır. Anket uygulanmadan önce araştırmacı tarafından öğretmenlerle yüz yüze görüşülmüş, öğretmenlere yöntemi tanıtan “Dramayla Öykü Oluşturma Yöntemi Bilgi Formu” ve içerisinde slaytlarla desteklenmiş etkinlik örnekleri bulunan "Tanıtım CD"si verilmiştir. Ayrıca öğretmenlerin yöntemle ilgili sorularına cevap verilmiş, son olarak öğretmenlerin kendi derslerinde örnek etkinlikler yapılarak "dramayla öykü oluşturma” yöntemi uygulamalı olarak tanıtılmıştır.

\section{BULGULAR VE YORUMLAR}

Bu bölüm öğretmenlerin kişisel-mesleki ve dramayla ilgili genel bilgilerini, drama yöntemiyle öykü oluşturma yöntemine ilişkin görüşlerini içeren bulgular ve bu bulgular ışığında yapılan yorumlardan oluşmaktadır.

\section{Ankete Katılan Türkçe Öğretmenlerinin Kişisel-Mesleki ve Drama Bilgileri ile İlgili Bulgular ve Yorumlar}

Bu bölüm öğretmenlerin kişisel-mesleki ve dramayla ilgili genel bilgilerini içeren bulgular ve bu bulgular ışığında yapılan yorumlardan oluşmaktadır. 
Ankete Katılan Türkçe Öğretmenlerinin Cinsiyetlerine İlişkin Bulgular ve Yorumlar Tablo-1: Ankete Katılan Türkçe Öğretmenlerinin Cinsiyetlerine İlişkin Bulgular

\begin{tabular}{||c|c|c||}
\hline & f & $\%$ \\
\hline Kadın & 23 & $52,3 \%$ \\
\hline Erkek & 21 & $47,7 \%$ \\
\hline
\end{tabular}

Tablo 1'e göre, araştırmaya katılan öğretmenlerin cinsiyet oranlarının birbirine yakın olduğu söylenebilir.

Ankete Katılan Türkçe Öğretmenlerinin Yaşlarına İlişkin Bulgular ve Yorumlar Tablo-2: Ankete Katılan Türkçe Öğretmenlerinin Yaşlarına İlişkin Bulgular

\begin{tabular}{||c|c|c||}
\hline & $\mathbf{f}$ & $\%$ \\
\hline $\mathbf{0 - 2 5}$ & 1 & $2,3 \%$ \\
\hline $\mathbf{2 6 - 3 0}$ & 19 & $43,2 \%$ \\
\hline $\mathbf{3 1 - 3 5}$ & 19 & $43,2 \%$ \\
\hline $\mathbf{3 6 - 4 0}$ & 1 & $2,3 \%$ \\
\hline $\mathbf{4 1 - 4 5}$ & 2 & $4,5 \%$ \\
\hline $\mathbf{4 5}$ ve üstü & 2 & $4,5 \%$ \\
\hline
\end{tabular}

Tablo 2'ye göre, öğretmenlerin 26-30 ve 31-35 yaş aralığında yoğunlaştığı, buna göre de ankete katılan öğretmenlerin orta yaş ve orta yaşın biraz altında olduğu söylenebilir.

Ankete Katılan Türkçe Öğretmenlerinin Çalıştıkları Okula İlişkin Bulgular ve Yorumlar Tablo-3: Ankete Katılan Türkçe Öğretmenlerinin Çalıştıkları Okula Illişkin Bulgular

\begin{tabular}{||l|c|c||}
\hline \multicolumn{1}{|l||}{} & $\mathbf{f}$ & $\%$ \\
\hline MEB'e bağlı resmî ilköğretim okulu & 44 & $100,0 \%$ \\
\hline MEB'e bağlı özel ilköğretim okulu & 0 & $0,0 \%$ \\
\hline
\end{tabular}

Tablo 3'e göre, araştırmaya katılan öğretmenlerin tamamının MEB'e bağlı resmî ilköğretim okulunda görev yaptığı görülmektedir.

Ankete Katılan Türkçe Öğretmenlerinin Eğitim Durumlarına i̇lişkin Bulgular ve Yorumlar Tablo-4: Ankete Katılan Türkçe Öğretmenlerinin Eğitim Durumlarına İlişkin Bulgular

\begin{tabular}{|l|c|c|}
\hline & $\mathbf{f}$ & $\%$ \\
\hline Eğitim Enstitüsü & 1 & $2,3 \%$ \\
\hline Ön Lisans & 0 & $0,0 \%$ \\
\hline Lisans & 41 & $93,2 \%$ \\
\hline Yüksek Lisans & 2 & $4,5 \%$ \\
\hline Doktora & 0 & $0,0 \%$ \\
\hline Diğer & 0 & $0,0 \%$ \\
\hline
\end{tabular}

Tablo 4'e göre, ankete katılan Türkçe öğretmenlerinin büyük bir çoğunluğunun lisans düzeyinde öğrenim gördükleri söylenebilir.

Ankete Katılan Türkçe Öğretmenlerinin Mezun Oldukları Bölüme İlişkin Bulgular ve Yorumlar

Tablo-5: Ankete Katılan Türkçe Öğretmenlerinin Mezun Oldukları Bölüme iliş̧kin Bulgular

\begin{tabular}{|c|c|c|}
\hline & $\bar{f}$ & $\%$ \\
\hline Türkçe Öğretmenliği & 18 & $40,9 \%$ \\
\hline Türk Dili ve Edebiyatı Öğretmenliği & 12 & $27,3 \%$ \\
\hline Türk Dili ve Edebiyatı (Fen-Edebiyat) & 12 & $27,3 \%$ \\
\hline Eğitim Enstitüsü Türkçe Bölümü & 1 & $2,3 \%$ \\
\hline Çağdaş Türk Lehçeleri ve Edebiyatı & 0 & $0,0 \%$ \\
\hline Yabancı Dil Öğretmenliği (Almanca-Fransızca Öğretmenliği) & 1 & $2,3 \%$ \\
\hline Diğer & 0 & $0,0 \%$ \\
\hline
\end{tabular}

Tablo 5'e göre, ankete katılan Türkçe öğretmenlerinin en fazla "Türkçe Öğretmenliği” bölümünden mezun oldukları söylenebilir. 
Türkçe Dersinde Dramayla Öykü Oluşturma Yönteminin Öğretmen Görüşlerine Göre Değerlendirilmesi

Ankete Katılan Türkçe Öğretmenlerinin Mesleklerindeki Hizmet Sürelerine illişkin Bulgular ve Yorumlar

Tablo-6: Ankete Katılan Türkçe Öğretmenlerinin Mesleklerindeki Hizmet Sürelerine ilişskin Bulgular

\begin{tabular}{||l|c|c||}
\hline & $\mathbf{f}$ & $\%$ \\
\hline $\mathbf{0 - 5}$ yıl & 12 & $27,3 \%$ \\
\hline $11-15 \mathrm{yıl}$ & 19 & $43,2 \%$ \\
\hline $16-20 \mathrm{yıl}$ & 9 & $20,5 \%$ \\
\hline $21-25$ yıl & 1 & $2,3 \%$ \\
\hline 26 ve sonrası & 1 & $2,3 \%$ \\
\hline
\end{tabular}

Tablo 6'ya göre, ankete katılan öğretmenlerin mesleklerinde hizmet sürelerinin en fazla 6-10 yıl aralığında yoğunlaştığı görülmektedir.

Ankete Katılan Türkçe Öğretmenlerinin Girdikleri Sınıfların Ortalama Öğrenci Sayısına i̇lişkin Bulgular ve Yorumlar

Tablo-7: Ankete Katılan Türkçe Öğretmenlerinin Girdikleri Sınıfların Ortalama Öğrenci Sayısına iliş̧kin Bulgular

\begin{tabular}{||l|c|c|}
\hline \hline $10-15$ & $\mathbf{f}$ & $\%$ \\
\hline $16-20$ & 0 & $0,0 \%$ \\
\hline $21-25$ & 1 & $2,3 \%$ \\
\hline $26-30$ & 13 & $29,5 \%$ \\
\hline $31-35$ & 23 & $52,3 \%$ \\
\hline 36 ve üstü & 7 & $15,9 \%$ \\
\hline
\end{tabular}

Tablo 7'ye göre, ankete katılan öğretmenlerin yarıdan fazlasının girdikleri sınıfların ortalama öğrenci sayısının 26-30 kişi aralığında olduğu görülmektedir.

Ankete Katılan Türkçe Öğretmenlerinin Eğitim Aldıkları Fakülte Programında Seçmeli ya da Zorunlu "Tiyatro", "Drama", "Tiyatro ve Drama Uygulamaları", "Tiyatro ve Canlandırma” Derslerinden Herhangi Birini Alıp Almadıklarına ilişskin Bulgular ve Yorumlar

Tablo-8: Ankete Katılan Türkçe Öğretmenlerinin Eğitim Aldıkları Fakülte Programında Seçmeli ya da Zorunlu "Tiyatro", "Drama", "Tiyatro ve Drama Uygulamaları", "Tiyatro ve Canlandırma" Derslerinden Herhangi Birini Alıp Almadıklarına ilişkin Bulgular

\begin{tabular}{||l|c|c||}
\hline & $\mathbf{f}$ & $\%$ \\
\hline Tiyatro & 13 & $29,5 \%$ \\
\hline Drama & 4 & $9,1 \%$ \\
\hline Tiyatro ve Drama Uygulamaları & 3 & $6,8 \%$ \\
\hline Tiyatro ve Canlandırma & 5 & $11,4 \%$ \\
\hline Hayır, tiyatro ve dramayla ilgili herhangi bir ders almadım. & 18 & $40,9 \%$ \\
\hline Diğer & 1 & $2,3 \%$ \\
\hline
\end{tabular}

*Bir öğretmen birden fazla seçeneği işaretleyebildiği için tablodaki yüzdeler, işaretlenen seçeneklerin yüzdesine karşlık gelmektedir.

Tablo 8'e göre araştırmaya katılan öğretmenlerin çoğunun eğitim aldıkları fakülte programlarında "Tiyatro", “Drama", "Tiyatro ve Drama Uygulamaları", "Tiyatro ve Canlandırma” derslerinden herhangi birini aldıkları söylenebilir. 
Ankete Katılan Türkçe Öğretmenlerinin “Drama, Dramatizasyon, Rol Oynama, Doğaçlama” Bilgilerine illişkin Bulgular ve Yorumlar

Tablo-9: Ankete Katılan Türkçe Öğretmenlerinin “Drama, Dramatizasyon, Rol Oynama, Doğaçlama” Bilgilerine illişkin Bulgular

\begin{tabular}{||l|c|c||}
\hline & $\mathbf{f}$ & $\%$ \\
\hline Hiç yok & 0 & $0,0 \%$ \\
\hline Çok az var & 3 & $6,8 \%$ \\
\hline Orta düzeyde var & 24 & $54,5 \%$ \\
\hline İyi düzeyde var & 15 & $34,1 \%$ \\
\hline Çok iyi düzeyde var & 2 & $4,5 \%$ \\
\hline
\end{tabular}

Tablo 9'a göre, araştırmaya katılan öğretmenlerin yarıdan fazlasının "drama, dramatizasyon, rol oynama, doğaçlama" kavramlarıyla ilgili orta düzeyde bilgi sahibi oldukları görülmektedir.

Ankete Katılan Türkçe Öğretmenlerinin Drama Yöntemini Kullanma Durumlarına ilişkin Bulgular ve Yorumlar

Tablo-10: Ankete Katılan Türkçe Öğretmenlerinin Drama Yöntemini Kullanma Durumlarına İlişkin Bulgular

\begin{tabular}{||l|c|c||}
\hline & $\mathbf{f}$ & $\%$ \\
\hline Evet & 13 & $29,5 \%$ \\
\hline Hayır & 5 & $11,4 \%$ \\
\hline Ara sıra & 26 & $59,1 \%$ \\
\hline
\end{tabular}

Tablo 10’a göre, araştırmaya katılan öğretmenlerin büyük çoğunluğunun Türkçe derslerinde drama yöntemini her zaman olmasa da ara sıra kullandıkları görülmektedir.

Ankete Katılan Türkçe Öğretmenlerinin Yeni Türkçe Programı́nın Drama Yöntemine Uygunluğu Hakkında Görüşlerini İçeren Bulgular ve Yorumlar

Tablo-11: Ankete Katılan Türkçe Öğretmenlerinin Yeni Türkçe Programı’nın Drama Yöntemine Uygunluğu Hakkında Görüşlerini İçeren Bulgular

\begin{tabular}{||l|c|c||}
\hline & $\mathbf{f}$ & $\%$ \\
\hline Evet & 15 & $34,1 \%$ \\
\hline Kısmen & 29 & $65,9 \%$ \\
\hline Hayır & 0 & $0,0 \%$ \\
\hline
\end{tabular}

Tablo 11'e göre, araştırmaya katılan öğretmenlerin büyük çoğunluğu Yeni Türkçe Programı'nın drama yöntemine kısmen uygun olduğu görüşündedir.

Ankete Katılan Türkçe Öğretmenlerinin Drama Yöntemi Uygularken En Çok Karşılaştıkları Güçlükle İlgili Bulgular ve Yorumlar

Tablo-12: Ankete Katılan Türkçe Öğretmenlerinin Drama Yöntemi Uygularken En Çok Karşılaştıkları Güçlüklerle İlgili Bulgular

\begin{tabular}{|c|c|c|}
\hline & $f$ & $\%$ \\
\hline Bu konuda yeterli bilgiye sahip olunmaması & 14 & $15,7 \%$ \\
\hline Ders saatlerinin yetersizliği & 22 & $24,7 \%$ \\
\hline Sınıftaki fiziki şartlarının uygunsuzluğu & 31 & $34,8 \%$ \\
\hline Sınıf mevcudunun fazla olması & 11 & $12,4 \%$ \\
\hline Öğrencilerin kendilerini rahat ve güvende hissetmemesi & 9 & $10,1 \%$ \\
\hline Okul idaresinin bu konuda engel olması & 0 & $0,0 \%$ \\
\hline Diğer & 2 & $2,2 \%$ \\
\hline
\end{tabular}


*Bir öğretmen birden fazla seçeneği işaretleyebildiği için tablodaki yüzdeler, işaretlenen seçeneklerin yüzdesine karşılık gelmektedir.

Tablo 12'ye göre, araştırmaya katılan öğretmenlerin drama yöntemini uygularken karşılaştıkları en büyük güçlük olarak sınıftaki fiziki şartların uygunsuzluğunu gösterdikleri görülmektedir. Özellikle ilköğretim okullarında drama etkinlikleri uygulanırken uygun dersliğin ve mekânın bulunmayışı büyük bir sorun olarak karşımıza çıkmaktadır.

Ankete Katılan Türkçe Öğretmenlerinin Yeni Türkçe Programı Çerçevesinde Okutulan Ders Kitaplarındaki Metinlerin Drama Yöntemine Uygunluğu Hakkında Görüşlerini İçeren Bulgular ve Yorumlar

Tablo-13: Ankete Katılan Türkçe Öğretmenlerinin Yeni Türkçe Programı Çerçevesinde Okutulan Ders Kitaplarındaki Metinlerin Drama Yöntemine Uygunluğu Hakkında Görüşlerini İçeren Bulgular

\begin{tabular}{||l|c|c||}
\hline & $\mathbf{f}$ & $\%$ \\
\hline Evet & 13 & $29,5 \%$ \\
\hline Kismen & 31 & $70,5 \%$ \\
\hline
\end{tabular}

Tablo 13'e göre, araştırmaya katılan öğretmenlerin büyük bir çoğunluğunun Yeni Türkçe Programı çerçevesinde okutulan ders kitaplarındaki metinlerin drama yöntemine kısmen uygun olduğu görüşünü savundukları görülmektedir.

Ankete Katılan Türkçe Öğretmenlerinin Drama Yönteminin Türkçe Derslerinde Hangi Alanın Gelişimine Katkı Sağladığıyla İlgili Görüşlerini İçeren Bulgular ve Yorumlar Tablo-14: Ankete Katılan Türkçe Öğretmenlerinin Drama Yönteminin Türkçe Derslerinde Hangi Alanın Gelişimine Katkı Sağladığıyla İlgili Görüşlerini İçeren Bulgular

\begin{tabular}{|c|c|c|}
\hline & 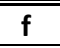 & $\%$ \\
\hline Temel dil becerilerini (okuma, yazma, dinleme, konuşma) geliştirir. & 41 & $32,8 \%$ \\
\hline Yaratıcılık ve hayal gücünü geliştirir. & 44 & $35,2 \%$ \\
\hline Dil bilgisi becerilerini geliştirir. & 20 & $16,0 \%$ \\
\hline Edebî türlerin kavratılmasına katkı sağlar. & 16 & $12,8 \%$ \\
\hline Diğer & 4 & $3,2 \%$ \\
\hline
\end{tabular}

*Bir öğretmen birden fazla seçeneği işaretleyebildiği için tablodaki yüzdeler, işaretlenen seçeneklerin yüzdesine karşılık gelmektedir.

Tablo 14'e göre, ankete katılan öğretmenlerin dramayla öykü oluşturma etkinliklerinin Türkçe derslerinde en çok yaratıcılık ve hayal gücünü geliştirdiği görüşünü savundukları görülmektedir.

Ankete Katılan Türkçe Öğretmenlerinin Türkçe Derslerinde Kullanmayı Uygun Buldukları Drama Tekniğiyle ilgili Bulgular ve Yorumlar

Tablo-15: Ankete Katılan Türkçe Öğretmenlerinin Türkçe Derslerinde Kullanmayı Uygun Buldukları Drama Tekniğiyle ilgili Bulgular

\begin{tabular}{||l|c|c||}
\hline \multicolumn{1}{|c|}{} & $\mathbf{f}$ & $\%$ \\
\hline Doğaçlama & 32 & $27,6 \%$ \\
\hline Rol Oynama & 33 & $28,4 \%$ \\
\hline Dramatizasyon & 31 & $26,7 \%$ \\
\hline Dansla Drama & 1 & $0,9 \%$ \\
\hline Kukla Draması & 2 & $1,7 \%$ \\
\hline Müzikle Drama & 4 & $3,4 \%$ \\
\hline Pandomim & 4 & $3,4 \%$ \\
\hline Rol Kartları & 9 & $7,8 \%$ \\
\hline Hiçbiri & 0 & $0,0 \%$ \\
\hline Diğer & 0 & $0,0 \%$ \\
\hline
\end{tabular}

*Bir öğretmen birden fazla seçeneği işaretleyebildiği iç̧in tablodaki yüzdeler, işaretlenen seçeneklerin yüzdesine karşılık gelmektedir. 
Tablo 15’e göre, ankete katılan öğretmenlerin en fazla "rol oynama" tekniğini kullanmayı uygun buldukları görülmektedir. "Rol oynama"dan sonra öğretmenler "doğaçlama" ve "dramatizasyon" tekniklerini dramada kullanılmayı uygun bulmuşlardır. Öğretmenlerin tekniklerle ilgili soruya verdikleri cevaplar incelendiğinde drama etkinliğinde teknikleri sınırlı tuttukları, tekniklerle ilgili yeterli bilgiye sahip olmadıkları görülmektedir.

Ankete Katılan Türkçe Öğretmenlerinin Türkçe Eğitiminde Dramayla Oluşturulan Öğretim Modelleri ve Tekniklerinin Kullanımının Yaygınlaşması için Önerdikleri Çalışmalarla İlgili Bulgular ve Yorumlar

Tablo-16: Ankete Katılan Türkçe Öğretmenlerinin Türkçe Eğitiminde Dramayla Oluşturulan Öğretim Modelleri ve Tekniklerinin Kullanımının Yaygınlaşması için Önerdikleri Çalışmalarla İlgili Bulgular

\begin{tabular}{|c|c|c|}
\hline & $\mathbf{f}$ & $\%$ \\
\hline Konuyla ilgili yazılı ve görsel kaynakların çoğaltılması & 27 & $22,3 \%$ \\
\hline Kurs ve seminerlerin açılması & 35 & $28,9 \%$ \\
\hline Bağımsız bir drama dersinin konulması & 33 & $27,3 \%$ \\
\hline Türkçe Öğretmenliği bölümündeki dramayla ilgili ders saatinin arttırılması & 26 & $21,5 \%$ \\
\hline Diğer & 0 & $0,0 \%$ \\
\hline
\end{tabular}

*Bir öğretmen birden fazla seçeneği işaretleyebildiği için tablodaki yüzdeler, işaretlenen seçeneklerin yüzdesine karşılık gelmektedir.

Tablo 16’ya göre, ankete katılan öğretmenlerin dramanın yaygınlaşması için önerdikleri seçenek "kurs ve seminerlerin açılması"dır. Bu çerçevede öğretmenler kendilerini bu yöntemle ilgili olarak hem teorik hem de uygulamalı olarak eğitmek istemektedirler.

Ankete Katılan Türkçe Öğretmenlerinin Dramayla Öykü Oluşturma Yöntemi Hakkında Görüşlerini İçeren Bulgular ve Yorumlar

Bu bölüm öğretmenlerin öykü oluşturma yöntemine ilişkin görüşlerini içeren bulgular ve bu bulgular ışığında yapılan yorumlardan oluşmaktadır.

Dramayla Öykü Oluşturma Yönteminde Mevcut Sınıf Ortamıyla İlgili Öğretmen Görüşlerini İçeren Bulgular ve Yorumlar

Tablo-17: Dramayla Öykü Oluşturma Etkinliklerinde Mevcut Sınıf Ortamıyla İgili Öğretmen Görüşlerini İçeren Bulgular

\begin{tabular}{||l|c|c||}
\hline \hline Dramayla öyküleştirme için mevcut sınıf ortamım uygundur. & $\mathbf{f}$ & $\%$ \\
\hline Tamamen Katılıyorum & 4 & $9,1 \%$ \\
\hline Katılıyorum & 6 & $13,6 \%$ \\
\hline Kararsızım & 6 & $13,6 \%$ \\
\hline Katılmıyorum & 24 & $54,5 \%$ \\
\hline Tamamen Katılmıyorum & 4 & $9,1 \%$ \\
\hline
\end{tabular}

Tablo 17’ye göre, "Dramayla öyküleştirme için mevcut sınıf ortamım uygundur." yargısına öğretmenlerin büyük bir kısmı katılmamaktadır.

Türkçe Ders Kitaplarında Dramayla Öykü Oluşturma Yöntemine Uygun Metinlere illişkin Öğretmen Görüşlerini İçeren Bulgular ve Yorumlar

Tablo-18: Türkçe Ders Kitaplarında Dramayla Öykü Oluşturma Yöntemine Uygun Metinlere iliş̧kin Öğretmen Görüşlerini iç̧eren Bulgular

\begin{tabular}{|c|c|c|}
\hline Türkçe ders kitabında dramayla öyküleştirmeye uygun metinler yoktur. & $\mathbf{f}$ & $\%$ \\
\hline Tamamen Katılıyorum & 0 & $0,0 \%$ \\
\hline Katılıyorum & 6 & $13,6 \%$ \\
\hline Kararsızım & 5 & $11,4 \%$ \\
\hline Katılmıyorum & 26 & $59,1 \%$ \\
\hline Tamamen Katılmıyorum & 7 & $15,9 \%$ \\
\hline
\end{tabular}


Türkçe Dersinde Dramayla Öykü Oluşturma Yönteminin Öğretmen Görüşlerine Göre Değerlendirilmesi

Tablo 18'e göre, "Türkçe ders kitabında dramayla öyküleştirmeye uygun metinler yoktur." yargısına öğretmenlerin büyük bir kısmı katılmamaktadır.

Dramayla Öykü Oluşturma Etkinlikleri Sırasında “Rol Oynama” ve “Doğaçlama" gibi Temel Drama Tekniklerinin Kullanılmasıyla İlgili Öğretmen Görüşlerini İçeren Bulgular ve Yorumlar

Tablo-19: Dramayla Öykü Oluşturma Etkinlikleri Sırasında "Rol Oynama” ve “Doğaçlama” gibi Temel Drama Tekniklerinin Kullanılmasıyla İlgili Öğretmen Görüşlerini İçeren Bulgular

\begin{tabular}{|c|c|c|}
\hline $\begin{array}{l}\text { Dramayla öyküleştirme sırasında rol oynama ve doğaçlama gibi temel teknikleri } \\
\text { kullanırım. }\end{array}$ & f & $\%$ \\
\hline Tamamen Katılıyorum & 11 & $25,0 \%$ \\
\hline Katılıyorum & 27 & $61,4 \%$ \\
\hline Kararsızım & 2 & $4,5 \%$ \\
\hline Katılmıyorum & 4 & $9,1 \%$ \\
\hline Tamamen Katılmıyorum & 0 & $0,0 \%$ \\
\hline
\end{tabular}

Tablo 19'e göre, öğretmenlerin çoğunluğu “Dramayla öyküleştirme sırasında rol oynama ve doğaçlama gibi temel teknikleri kullanırım." yargısında birleşmektedir.

Türkçe Öğretmenlerinin Dramayla Öykü Oluşturma Etkinliklerini Yürütebilmek, Yönlendirebilmek İçin Yeterli Tiyatro ve Oyunculuk Bilgisine Sahip Olma Durumlarıyla İlgili Görüşlerini İçeren Bulgular ve Yorumlar

Tablo-20: Türkçe Öğretmenlerinin Dramayla Öykü Oluşturma Etkinliklerini Yürütebilmek, Yönlendirebilmek İçin Yeterli Tiyatro ve Oyunculuk Bilgisine Sahip Olma Durumlarıyla İlgili Görüşlerini İçeren Bulgular

\begin{tabular}{|c|c|c|}
\hline $\begin{array}{l}\text { Dramayla öyküleştirme etkinliklerini yürütebilmek ve yönlendirebilmek için yeterli tiyatro } \\
\text { ve oyunculuk bilgisine sahibim. }\end{array}$ & $\mathbf{F}$ & $\%$ \\
\hline Tamamen Katılıyorum & 2 & $4,5 \%$ \\
\hline Katılıyorum & 17 & $38,6 \%$ \\
\hline Kararsızım & 11 & $25,0 \%$ \\
\hline Katılmıyorum & 13 & $29,5 \%$ \\
\hline Tamamen Katılmıyorum & 1 & $2,3 \%$ \\
\hline
\end{tabular}

Tablo 20’ye göre, öğretmenlerin büyük bir kısmı “Dramayla öyküleştirme etkinliklerini yürütebilmek ve yönlendirebilmek için yeterli tiyatro ve oyunculuk bilgisine sahibim." yargısında birleşmektedir.

Hikâye, Masal, Fıkra gibi İçerisinde Diyalog ve Dramatik Kurgular Bulunan Metinlerin Dramayla Öykü Oluşturma Yöntemiyle Öğretilmesi Üzerine Öğretmen Görüşlerini İçeren Bulgular ve Yorumlar

Tablo-21: Hikâye, Masal, Fıkra gibi İçerisinde Diyalog ve Dramatik Kurgular Bulunan Metinlerin Dramayla Öykü Oluşturma Yöntemiyle Öğretilmesi Üzerine Öğretmen Görüşlerini İçeren Bulgular

\begin{tabular}{|c|c|c|}
\hline $\begin{array}{l}\text { Hikâye, masal, fikra gibi içerisinde diyalog ve dramatik kurgular bulunan metinler drama } \\
\text { yöntemiyle öğretilmelidir. }\end{array}$ & $\mathbf{f}$ & $\%$ \\
\hline Tamamen Katılıyorum & 12 & $27,3 \%$ \\
\hline Katılıyorum & 29 & $65,9 \%$ \\
\hline Kararsızım & 1 & $2,3 \%$ \\
\hline Katılmıyorum & 2 & $4,5 \%$ \\
\hline Tamamen Katılmıyorum & 0 & $0,0 \%$ \\
\hline
\end{tabular}

Tablo 21'e göre, öğretmenlerin çoğunluğu “Hikâye, masal, fıkra gibi içerisinde diyalog ve dramatik kurgular bulunan metinler drama yöntemiyle öğretilmelidir." yargısında birleşmektedir.

Dramayla Öykü Oluşturma Yönteminin Temel Dil Becerilerinden Konuşma Eğitiminin Kazandırılmasına Etkisiyle İlgili Öğretmen Görüşlerini İçeren Bulgular ve Yorumlar. 
Tablo-22: Dramayla Öykü Oluşturma Yönteminin Temel Dil Becerilerinden Konuşma Eğitiminin Kazandırılmasına Etkisiyle ilgili Öğretmen Görüşlerini İçeren Bulgular

\begin{tabular}{||l|c|c||}
\hline $\begin{array}{l}\text { Dramayla oluşturulmuş öyküler temel dil becerilerinden konuşma eğitiminin } \\
\text { kazandırılmasında etkilidir. }\end{array}$ & f \\
\hline Tamamen Katılıyorum & 23 & $52,3 \%$ \\
\hline Katılıyorum & $47,7 \%$ \\
\hline Kararsızım & $0,0 \%$ & 0 \\
\hline Katılmıyorum & $0,0 \%$ \\
\hline Tamamen Katılmıyorum & $0,0 \%$ \\
\hline
\end{tabular}

Tablo 22'ye göre, öğretmenlerin çoğunluğu “Dramayla oluşturulmuş öyküler temel dil becerilerinden konuşma eğitiminin kazandırılmasında etkilidir." yargısında birleşmektedir.

Dramayla Öykü Oluşturma Yönteminin Temel Dil Becerilerinden Dinleme Eğitiminin Kazandırılmasında Etkisiyle İlgili Öğretmen Görüşlerini İçeren Bulgular ve Yorumlar

Tablo-23: Dramayla Öykü Oluşturma Yönteminin Temel Dil Becerilerinden Dinleme Eğitiminin Kazandırılmasına Etkisiyle ilgili Öğretmen Görüşlerini İçeren Bulgular

\begin{tabular}{||l|c|c||}
\hline $\begin{array}{l}\text { Dramayla oluşturulmuş öyküler temel dil becerilerinden dinleme eğitiminin } \\
\text { kazandırılmasında etkilidir. }\end{array}$ & $\mathbf{f}$ & $\%$ \\
\hline Tamamen Katılıyorum & 14 & $31,8 \%$ \\
\hline Katılıyorum & 24 & $54,5 \%$ \\
\hline Kararsızım & 3 & $6,8 \%$ \\
\hline Tamalımıyorum & 3 & $6,8 \%$ \\
\hline
\end{tabular}

Tablo 23'e göre, öğretmenlerin çoğunluğu “Dramayla oluşturulmuş öyküler temel dil becerilerinden dinleme eğitiminin kazandırılmasında etkilidir." yargısında birleşmektedir.

Dramayla Öykü Oluşturma Yönteminin Temel Dil Becerilerinden Yazma Eğitiminin Kazandırılmasına Etkisiyle ilgili Öğretmen Görüşlerini İçeren Bulgular ve Yorumlar

Tablo-24: Dramayla Öykü Oluşturma Yönteminin Temel Dil Becerilerinden Yazma Eğitiminin Kazandırılmasına Etkisiyle ilgili Öğretmen Görüşlerini İçeren Bulgular

\begin{tabular}{|c|c|c|}
\hline $\begin{array}{l}\text { Dramayla oluşturulmuş öyküler temel dil becerilerinden yazma eğitiminin kazandırılmasında } \\
\text { etkilidir. }\end{array}$ & $f$ & $\%$ \\
\hline Tamamen Katılıyorum & 7 & $15,9 \%$ \\
\hline Katılıyorum & 24 & $54,5 \%$ \\
\hline Kararsızım & 7 & $15,9 \%$ \\
\hline Katılmıyorum & 5 & $11,4 \%$ \\
\hline Tamamen Katılmıyorum & 1 & $2,3 \%$ \\
\hline
\end{tabular}

Tablo 24'e göre, öğretmenlerin çoğunluğu “Dramayla oluşturulmuş öyküler temel dil becerilerinden yazma eğitiminin kazandırılmasında etkilidir." yargısında birleşmektedir.

Dramayla Öykü Oluşturma Yönteminin Temel Dil Becerilerinden Okuma Eğitiminin Kazandırılmasına Etkisiyle ilgili Öğretmen Görüşlerini İçeren Bulgular ve Yorumlar

Tablo-25: Dramayla Öykü Oluşturma Yönteminin Temel Dil Becerilerinden Okuma Eğitiminin Kazandırılmasına Etkisiyle ilgili Öğretmen Görüşlerini iç̧eren Bulgular

\begin{tabular}{||l|c|c||}
\hline $\begin{array}{l}\text { Dramayla oluşturulmuş öyküler temel dil becerilerinden okuma eğitiminin } \\
\text { kazandırımasında etkilidir. }\end{array}$ & $\mathbf{f}$ & $\%$ \\
\hline Tamamen Katılıyorum & 7 & $15,9 \%$ \\
\hline Katılıyorum & 28 & $63,6 \%$ \\
\hline Kararsızım & 3 & $6,8 \%$ \\
\hline Katılmıyorum & 5 & $11,4 \%$ \\
\hline
\end{tabular}


Tablo 25’e göre, öğretmenlerin çoğunluğu “Dramayla oluşturulmuş öyküler temel dil becerilerinden okuma eğitiminin kazandırılmasında etkilidir." yargısında birleşmektedir.

Dramayla Öykü Oluşturma Yönteminin Dil Bilgisi Öğretimine Katkısıyla illgili Öğretmen Görüşlerini i̇çeren Bulgular ve Yorumlar

Tablo-26: Dramayla Öykü Oluşturma Yönteminin Dil Bilgisi Öğretimine Katkısıyla ilgili Öğretmen Görüşlerini iç̧eren Bulgular

\begin{tabular}{|c|c|c|}
\hline Dramayla oluşturulmuş öyküler dil bilgisi öğretiminde etkilidir. & f & $\%$ \\
\hline Tamamen Katılıyorum & 6 & $13,6 \%$ \\
\hline Katılıyorum & 25 & $56,8 \%$ \\
\hline Kararsızım & 9 & $20,5 \%$ \\
\hline Katılmıyorum & 4 & $9,1 \%$ \\
\hline Tamamen Katılmıyorum & 0 & $0,0 \%$ \\
\hline
\end{tabular}

Tablo 26’ya göre, öğretmenlerin çoğunluğu "Dramayla oluşturulmuş öyküler dil bilgisi öğretiminde etkilidir." yargısında birleşmektedir.

Dramayla Öykü Oluşturma Yönteminin Yaratıcılık ve Hayal Gücünün Kazandırılmasına Etkisiyle İlgili Öğretmen Görüşlerini İçeren Bulgular ve Yorumlar

Tablo-27: Dramayla Öykü Oluşturma Yönteminin Yaratıcılık ve Hayal Gücünün Kazandırılmasına Etkisiyle İlgili Öğretmen Görüşlerini İçeren Bulgular

\begin{tabular}{|c|c|c|}
\hline Dramayla oluşturulmuş öyküler yaratıcılık ve hayal gücünün kazandırılmasında etkilidir. & f & $\%$ \\
\hline Tamamen Katılıyorum & 31 & $70,5 \%$ \\
\hline Katılıyorum & 13 & $29,5 \%$ \\
\hline Kararsızım & 0 & $0,0 \%$ \\
\hline Katılmıyorum & 0 & $0,0 \%$ \\
\hline Tamamen Katılmıyorum & 0 & $0,0 \%$ \\
\hline
\end{tabular}

Tablo 27’ye göre, öğretmenlerin çoğunluğu “Dramayla oluşturulmuş öyküler yaratıcılık ve hayal gücünün kazandırılmasında etkilidir." yargısında birleşmektedir.

Dramayla Öykü Oluşturma Yöntemiyle İşlenen Türkçe Dersinde Bilgilerin Kalıcılığı Açısından Öğretmen Görüşlerini İçeren Bulgular ve Yorumlar

Tablo-28: Dramayla Öykü Oluşturma Yöntemiyle İşlenen Türkçe Dersinde Bilgilerin Kalıcılığı Açısından Öğretmen Görüşlerini İçeren Bulgular

\begin{tabular}{|c|c|c|}
\hline $\begin{array}{l}\text { Dramayla oluşturulmuş öykülerle işlenen ders Türkçe eğitimine kalıcılık açısından olumlu bir } \\
\text { katkı sağlar. }\end{array}$ & $f$ & $\%$ \\
\hline Tamamen Katılıyorum & 28 & $63,6 \%$ \\
\hline Katılıyorum & 15 & $34,1 \%$ \\
\hline Kararsızım & 1 & $2,3 \%$ \\
\hline Katılmıyorum & 0 & $0,0 \%$ \\
\hline Tamamen Katılmıyorum & 0 & $0,0 \%$ \\
\hline
\end{tabular}

Tablo 28'e göre, öğretmenlerin çoğunluğu “Dramayla oluşturulmuş öykülerle işlenen ders Türkçe eğitimine kalıcılık açısından olumlu bir katkı sağlar." yargısında birleşmektedir.

Dramayla Öykü Oluşturma Yönteminin Türkçe Derslerinde Kolaylıkla Kullanılabileceğiyle İlgili Öğretmen Görüşlerini İçeren Bulgular ve Yorumlar

Tablo-29: Dramayla Öykü Oluşturma Yönteminin Türkçe Derslerinde Kolaylıkla Kullanılabileceğiyle ilgili Öğretmen Görüşlerini İçeren Bulgular 


\begin{tabular}{|c|c|c|}
\hline $\begin{array}{l}\text { Dramayla öykü oluşturma ikinci kademe Türkçe derslerinde kolaylıkla kullanılabilecek bir } \\
\text { yöntemdir. }\end{array}$ & f & $\%$ \\
\hline Tamamen Katılıyorum & 15 & $34,1 \%$ \\
\hline Katılıyorum & 23 & $52,3 \%$ \\
\hline Kararsızım & 3 & $6,8 \%$ \\
\hline Katılmıyorum & 2 & $4,5 \%$ \\
\hline Tamamen Katılmıyorum & 1 & $2,3 \%$ \\
\hline
\end{tabular}

Tablo 29’a göre, öğretmenlerin çoğunluğu “Dramayla öykü oluşturma ikinci kademe Türkçe derslerinde kolaylıkla kullanılabilecek bir yöntemdir." yargısında birleşmektedir.

Dramayla Öykü Oluşturma Yönteminin Iilköğretim Programında Yer Almasının Yararlı Olacağıyla İlgili Öğretmen Görüşlerini İçeren Bulgular ve Yorumlar

Tablo-30: Dramayla Öykü Oluşturma Yönteminin İlköğretim Programında Yer Almasının Yararlı Olacağıyla İlgili Öğretmen Görüşlerini İçeren Bulgular

\begin{tabular}{|l|c|c||}
\hline $\begin{array}{l}\text { Dramayla öykü oluşturma yönteminin ilköğretim programında yer almasının faydalı } \\
\text { olacağını düşünüyyorum. }\end{array}$ & $\mathbf{f}$ & $\%$ \\
\hline Tamamen Katılıyorum & 23 & $52,3 \%$ \\
\hline Katılıyorum & 20 & $45,5 \%$ \\
\hline Kararsızım & 1 & $2,3 \%$ \\
\hline Katılmıyorum & 0 & $0,0 \%$ \\
\hline Tamamen Katılmıyorum & 0 & $0,0 \%$ \\
\hline
\end{tabular}

Tablo 30’a göre, öğretmenlerin çoğunluğu “Dramayla öykü oluşturma yönteminin ilköğretim programında yer almasının faydalı olacağını düşünüyorum." yargısında birleşmektedir.

Dramayla Öykü Oluşturma Yönteminin Öğrencinin Türkçeyi Sevmesine Katkı Sağlamasıyla i̇lgili Öğretmen Görüşlerini İçeren Bulgular ve Yorumlar

Dramayla öykü oluşturma yönteminin öğrencinin Türkçeyi sevmesine katkı sağlamasıyla ilgili öğretmen görüşlerini içeren bulgular Tablo 31'de verilmiştir.

Tablo-31: Dramayla Öykü Oluşturma Yönteminin Öğrencinin Türkçeyi Sevmesine Katkı Sağlamasıyla ilgili Öğretmen Görüşlerini İçeren Bulgular

\begin{tabular}{|c|c|c|}
\hline Dramayla oluşturulmuş öyküler öğrencinin Türkçeyi sevmesine yardımcı olur. & f & $\%$ \\
\hline Tamamen Katılıyorum & 30 & $68,2 \%$ \\
\hline Katılıyorum & 14 & $31,8 \%$ \\
\hline Kararsızım & 0 & $0,0 \%$ \\
\hline Katılmıyorum & 0 & $0,0 \%$ \\
\hline Tamamen Katılmıyorum & 0 & $0,0 \%$ \\
\hline
\end{tabular}

Tablo 31'e göre, öğretmenlerin çoğunluğu “Dramayla oluşturulmuş öyküler öğrencinin Türkçeyi sevmesine yardımcı olur." yargısında birleşmektedir.

\section{SONUÇ VE TARTIŞMA}

Araştırmaya katılan öğretmenler dramayla oluşturulmuş öykülerin öğrencilerin Türkçeyi sevmesine yardımcı olacağı fikrinde birleşmektedirler. Öğretmenler drama yöntemini uygularken karşılaştıkları en büyük güçlüğü fiziki şartların uygun olmayışı olarak ifade etmekte ve ilköğretim okullarında drama etkinlikleri uygulanırken uygun dersliğin ve alanın bulunmayışını büyük bir sorun olarak görmektedirler. Veriler incelendiğinde ortalama 
öğrenci sayısının 26-30 kişi aralığında görülmesine rağmen öğretmenlerin dramayla öykü oluşturma yönteminde mevcut öğrenci sayısının etkinlik yapılmasına engel olmadığı görüşünde birleşirler. Bu durumun sebebi araştırmacının kalabalık sınıflara uygun etkinlikleri tercih etmesiyle açıklanabilir. Öğretmenler ayrıca dramayla öykü oluşturma yönteminde mevcut ders saatinin yeterli olmadığı görüşündedirler. Araştırmaya katılan öğretmenler dramayla oluşturulmuş öykülerin temel dil becerilerinden konuşma, dinleme, yazma, okuma eğitiminin kazandırılmasında ve dilbilgisi öğretiminde etkili olduğunu savunmuşlardır. Veriler incelendiğinde dramayla öykü oluşturma yönteminin temel dil becerilerinden özellik konuşma ve dinlemede etkili olduğu görülmektedir. Pamale Bowell'e göre de dil öğretiminde konuşma dinleme, okuma, yazma becerileri içerisinde drama çalışmaları daha çok konuşma ve dinleme alanına yöneliktir (Aktaran: Kayhan, 2004: 13-14). Ayrıca öğretmenler bu etkinliklerinin Türkçe derslerinde en çok yaratıcılık ve hayal gücünü geliştirdiği görüşünü savunmuşlardır. Kavcar'a (2006: 25) göre de öğrencilerin bildikleri bir öykünün yine kendileri tarafından canlandırılması veya o anda oluşturulan bir öykünün dramatize edilmesi, onları o an içinde bulundukları ortamdan alıp götürür. Böylece yaratıcılık yolları da alabildiğine açılır.

Öğretmenlerin çoğunun lisans döneminde "Tiyatro", "Drama", "Tiyatro ve Drama Uygulamaları", "Tiyatro ve Canlandırma" derslerinden herhangi birini aldıkları ve yarıdan fazlasının "drama, dramatizasyon, rol oynama, doğaçlama” kavramlarıyla ilgili bilgi sahibi oldukları görülmektedir. Öğretmenlerin dramayla öykü oluşturma etkinliklerini yürütebilmek, yönlendirmek için yeterli tiyatro ve oyunculuk bilgisine sahip olduklarını ifade etmelerine rağmen çoğunun Türkçe derslerinde drama yöntemini ara sıra kullandıkları görülmektedir. Bu uygulamalarda ise en çok "rol oynama" sonra da "doğaçlama" ve "dramatizasyon" tekniklerini tercih etmişlerdir. Öğretmenlerin büyük çoğunluğu “Yeni Türkçe Programı”nın ve bu çerçevede okutulan ders kitaplarındaki metinlerin drama yöntemine kısmen uygun olduğunu ve mevcut Türkçe ders kitaplarında dramaya uygun metinlerin yeterli olmadığını, hikâye, masal, fıkra gibi içerisinde diyalog ve dramatik kurgular bulunan metinlerin drama yöntemiyle öğretilmesi gerektiğini ifade etmektedirler. Aykaç ve Uluğbey'e (2008: 157-158) göre de İlköğretim Türkçe kitaplarındaki etkinlikler incelendiğinde, diğer derslere oranla genel olarak drama çalışmalarına geniş yer verildiği görülmektedir. Ancak Türkiye'de birçok konunun drama yöntemiyle işlenmeye uygun olduğu dikkate alındığında dramaya yeterli oranda yer verildiğini söylemek oldukça güçtür. Dramanın anlama (dinleme-okuma) ve anlatma (konuşma-yazma) becerileri üzerindeki etkisi de düşünüldüğünde, Türkçe programlarında yaratıcı dramaya daha geniş oranda yer verilmesi gerekliliği ortaya çıkmaktadır.

Öğretmenlere göre dramayla oluşturulmuş öykülerle işlenen Türkçe dersi daha kalıcıdır ve bu yöntem Türkçe derslerinde kolaylıkla uygulanabilir. Araştırmaya katılan öğretmenler dramayla öykü oluşturma yönteminin ilköğretim programında yer almasının faydalı olacağını savunmaktadırlar.

\section{ÖNERILER}

1. Türkçe ders saati arttırılarak ders saati içerisinde "drama" ya yeterli süre ayrılmalıdır. Gerekirse okullara bağımsız "drama” dersi konulmalıdır. 
2. Dramayla öykü oluşturma etkinlikleri yaşlara ve sınıflara uygun olarak seçilmelidir.

3. Türkçe ders kitaplarında öyküleştirmeye uygun metinler hazırlanmalıdır.

4. Türkçe öğretmenlerine hizmet içi eğitim kurslarında ve ilgili seminerlerde drama konusunda eğitim verilmelidir.

5. Türkçe dersinde drama yönteminin uygulanmasıyla ilgili görsel ve yazılı kaynaklara, materyallere önem verilmelidir.

6. Drama etkinlikleri için uygun araç ve gerece kolaylıkla ulaşılmalıdır.

7. Yapılandırmacı eğitim yaklaşımı çerçevesinde Türkçe ders programı yeniden ele alınmalı, drama bir yöntem ya da model olarak ders programında işlevsel olarak yerini almalıdır.

8. Okullardaki fiziksel yetersizlikler dramayla öykü oluşturma yönteminin uygulanmasını olumsuz yönde etkilemektedir. Eğitimin daha çağdaş ve etkin bir şekilde yapılabilmesi için fiziksel şartların uygun hale dönüştürülmesi zorunludur.

\section{Kaynaklar}

Adıgüzel, Ö. (2007). "Dramada Temel Kavramlar". (Editör: Ali Öztürk). IIlköğretimde Drama (1. Baskı). Eskişehir: Anadolu Üniversitesi Yayınları, s.1-18.

Akar, R. (2000). Temel Eğitimin İkinci Aşamasında Drama Yöntemi İle Türkçe Öğretimi: Dorothy Heathcote'un Uzman Rolü Yaklaşımı, Yayımlanmamış Yüksek Lisans Tezi, Çukurova Üniversitesi Sosyal Bilimler Enstitüsü, Adana.

Aksoy Tokgöz, ì. (2004). Illköğretim 4. ve 5. Sınıf Türkçe Programlarında Edebî Türlerden Öykünün Öğretiminde Yaratıcı Drama Yönteminin Etkililiği. Yayımlanmamış Yüksek Lisans Tezi, Çanakkale 18 Mart Üniversitesi Sosyal Bilimler Enstitüsü, Çanakkale.

And, M. (1974). Oyun ve Bügü. İstanbul: Türkiye İş Bankası Yayınları.

Aslan, N. (2009). "Drama Öğretimi", Türkiye 10. Drama Liderleri Buluşması ve Ulusal Drama Semineri Kitabı. 20- 22 Haziran, Ankara: Oluşum Yayınları, 25-29.

Aykaç, N. ve Uluğbey, Ö. (2008). "Yaratıcı Drama Yöntemi İle Yapılandırmacılık İlişkisinin 2005 MEB İlköğretim Programlarında Değerlendirilmesi”, 13. Uluslararası Eğitimde Yaratıcı Drama / Tiyatro Kongresi Bildiri Kitabı, 21- 22 Kasım, Ankara: SMG Yayıncılık, s. 144-164.

Bayer, M. (2006). Sokak Çocuklarının Eğitiminde Drama ve Tiyatronun Kullanılması ve Bir Uygulama. Yayımlanmamış Yüksek Lisans Tezi, Ankara Üniversitesi Sosyal Bilimler Enstitüsü, Ankara.

Çakar, A. (2007). Din ve Ahlâk Eğitiminde Hikâyenin Kullanımı, Yayımlanmamış Yüksek Lisans Tezi. Rize Üniversitesi Sosyal Bilimler Enstitüsü, Rize.

İpek, A. (1998). Eğitimde Dramanın Zihinsel Engelli Çocukların Sosyal Gelişimleri Üzerinde Etkisinin incelenmesi. Yayımlanmamış Yüksek Lisans Tezi, Hacettepe Üniversitesi Sağlık Bilimleri Enstitüsü, Ankara. 
Türkçe Dersinde Dramayla Öykü Oluşturma Yönteminin Öğretmen Görüşlerine Göre Değerlendirilmesi

İşleyen, E. (2009). Ortaöğretim Dokuzuncu Sınıf Türk Edebiyatı Dersinde Drama Yönteminin Öğrencilerin Ders Başarısına Katkısı (Ankara Ili-Akyurt Il/çesi Örneği), Yayımlanmamış Yüksek Lisans Tezi, Gazi Üniversitesi Eğitim Bilimleri Enstitüsü, Ankara.

Kara, Ö. T. (2000). Türkçe Öğretiminde Yaratıcı Drama. Yayımlanmamış Yüksek Lisans Tezi, Atatürk Üniversitesi Sosyal Bilimler Enstitüsü, Erzurum.

Karakuş, F. (2000). Drama Yönteminin Ilköğretim Beşinci Sınıf Öğrencilerinin Öykü Yazma Becerilerine Etkisi. Yayımlanmamış Yüksek Lisans Tezi, Çukurova Üniversitesi Sosyal Bilimler Enstitüsü, Adana.

Karasar, Niyazi (1991). Bilimsel Araştırma Yöntemi (4. Basım). Ankara: 3A Araştırma Eğitim Danışmanlık Ltd. Şti.

Karateke, E. (2006). Yaratıcı Dramanın IIlköğretim II. Kademede 6. Sınıf Öğrencilerinin Yazılı Anlatım Becerilerine Olan Etkisi. Yayımlanmamış Yüksek Lisans Tezi, Mustafa Kemal Üniversitesi Sosyal Bilimler Enstitüsü, Hatay.

Kavcar, C. (2006). “Örgün Eğitimde Dramatizasyon”. (Editör: H. Ömer Adıgüzel). Yaratıcı Drama (1985-1998 Yazılar) Ankara: Naturel Yayınları, s.18-28

Kayhan, H. C. (2004). Yaratıcı Dramanın Ilköğretim 3. Sınıf Matematik Dersinde Öğrenmeye, Bilgilerin Kalıcılığına ve Matematiğe Yönelik Tutumlara Etkesi. Yayımlanmamış Yüksek Lisans Tezi, Gazi Üniversitesi Eğitim Bilimleri Enstitüsü, Ankara.

Kazıcı, E. (2008). Illköğretim Ikinci Kademe Türkçe Derslerinde Deyim ve Atasözlerinin Öğretiminde Dramatizasyon Yönteminin Etkililik Düzeyi. Yayımlanmamış Yüksek Lisans Tezi, Selçuk Üniversitesi Sosyal Bilimler Enstitüsü, Konya.

Koç, K. (2009). ilköğretim 7. Sınıf Türkçe Dersinde Dramatizasyonla Yaratıcı Dramanın Karşılaştırılması. Yayımlanmamış Yüksek Lisans Tezi, Ondokuz Mayıs Üniversitesi Sosyal Bilimler Enstitüsü, Samsun.

Köklü, S. (2003). Türkçe Öğretiminde 7. ve 8. Sınıf Öğrencilerine Dinlediğini Anlama Davranışının Kazandırılmasına Dramatizasyonun Etkisi. Yayımlanmamış Yüksek Lisans Tezi, Marmara Üniversitesi Eğitim Bilimleri Enstitüsü, İstanbul.

Oğuzkan, A. Ferhan (1993). Eğitim Terimleri Sözlüğü. Ankara: Emel Matbaacılık.

Özcan, H. (2004). Illköğretim 5. Sınıf Sosyal Bilgiler Dersi Coğrafya Konularının Öğretiminde Drama Yönteminin Kullanılması (Kazan IIlçesi Örneği). Yayımlanmamış Yüksek Lisans Tezi, Gazi Üniversitesi Eğitim Bilimleri Enstitüsü, Ankara.

San, İ. (1990). Eğitimde Yaratıcı Drama. Ankara Üniversitesi Eğitim Bilimleri Fakültesi Dergisi, 23 (2), 573-582.

Sönmez, K. (2006). Illköğretim Ikinci Kademedeki Türkçe Ders Kitaplarında Yaratıcı Drama Yoluyla Işlenebilecek Metinlerin Çözümlenmesi. Yayımlanmamış Yüksek Lisans Tezi, Ondokuz Mayıs Üniversitesi Sosyal Bilimler Enstitüsü, Samsun. 
Uyar, N. (1995). Anaokuluna Devam Eden 60-72 Aylık Çocuklara Destekleyici Olarak Uygulanan Eğitiminde Drama Programının Çocukların Dil Gelişimine Etkisinin Incelenmesi. Yayımlanmamış Yüksek Lisans Tezi, Hacettepe Üniversitesi Sosyal Bilimler Enstitüsü, Ankara.

Uzuner, S. (2007). Yenilenen Program Çerçevesinde Birinci Kademe Türkçe Ders Kitaplarında Yer Alan 'Öyküleyici Metinler'in Sınıf Öğretmenleri Açısından Algılanma Yeterliliklerinin Tespit ve Türkçe Öğretiminin Amaçlarına Uygunluğunun Belirlenmesi. Yayımlanmamış Yüksek Lisans Tezi, Atatürk Üniversitesi Sosyal Bilimler Enstitüsü, Erzurum.

Ünsal, B. (2005). ilköğretim Ikinci Kademe (6, 7, 8. Sınıflar)Türkçe Dersinde Drama Yönteminin Çocukların Dil ve Anlatım Becerilerine Katkısı. Yayımlanmamış Yüksek Lisans Tezi, Gazi Üniversitesi Eğitim Bilimleri Enstitüsü, Ankara.

Yiğit, E. Ö. (2007). Öyküleştirme Yönteminin 6. Sınıf Sosyal Bilgiler Programı Ülkemizin Kaynakları Ünitesindeki Öğrenci Başarısı Üzerine Etkisi. Yayımlanmamış Yüksek Lisans Tezi, Abant İzzet Baysal Üniversitesi Sosyal Bilimler Enstitüsü, Bolu. 